\title{
Changes in growth, hormones levels and essential oil content of Ammi visnaga plants treated with some bioregulators
}

\author{
IMAN M. TALAAT ${ }^{1}$, HEMMAT I. KHATTAB ${ }^{2}$, AISHA M. AHMED ${ }^{1, \bullet}$ \\ ${ }^{1}$ Botany Department, National Research Centre, Cairo, Egypt. Tel.: +20-1140355848, Fax.: +20-233370931, "email: aishazyat@ yahoo.com \\ ${ }^{2}$ Botany Department, Faculty of Science, Ain-Shams University, Cairo, Egypt.
}

Manuscript received: 6 August 2013. Revision accepted: 10 September 2013.

\begin{abstract}
Talaat IM, Khattab HI, Ahmed AM. 2013. Changes in growth, hormones levels and essential oil content of Ammi visnaga plants treated with some bioregulators. Nusantara Bioscience 5: 57-64. The effects of foliar application of different concentrations of amino acids (tyrosine and phenylalanine) and phenolic acids (trans-cinnamic acid, benzoic acid, and salicylic acid) on growth, pigment content, hormones levels and essential oil content of Ammi visnaga $\mathrm{L}$ were carried out during two successive seasons. It is clear that foliar application of either amino acids or phenolics significantly promoted the growth parameters in terms of shoot height, fresh and dry biomass, number of branches and number of umbels per plant. The increment of growth parameter was associated with elevated levels of growth promoters (IAA, GA3, total cytokinins) and low level of ABA. The greatest increase in the previously mentioned parameters was measured in plants exposed to different concentrations of phenols particularly in benzoic acid-treated plants. Such effect was concentration dependent. All treatments led to significant increments in seed yield and essential oil content. Moreover, Gas-Liquid Chromatographic analysis revealed that the main identified components of essential oil were 2,2-dimethyl butanoic acid, isobutyl isobutyrate, $\alpha$-isophorone, thymol, fenchyl acetate, and linalool. Phenolics and amino acids treatments resulted in qualitative differences in these components of oil.
\end{abstract}

Keywords: Ammi visnaga, phenolic compounds, amino acids, hormones, growth criteria, essential oil

\begin{abstract}
Abstrak. Talaat IM, Khattab HI, Ahmed AM. 2013. Perubahan dalam pertumbuhan, kadar hormon dan kandungan minyak atsiri tanaman Ammi visnaga yang diperlakukan dengan beberapa bioregulator. Nusantara Bioscience 5: 57-64. Pengaruh aplikasi daun berbagai konsentrasi asam amino (tirosin dan fenilalanin) dan asam fenolat (asam trans-sinamat, asam benzoat dan asam salisilat) terhadap pertumbuhan, kandungan pigmen, kadar hormon dan kandungan minyak atsiri Ammi visnaga L. telah dilakukan selama dua musim berturut-turut. Hasilnya secara jelas menunjukkan bahwa aplikasi daun dari salah satu asam amino atau asam fenolat secara signifikan meningkatkan parameter pertumbuhan dalam hal tinggi tunas, biomassa segar dan kering, jumlah cabang dan jumlah tangkai bunga per tanaman. Kenaikan parameter pertumbuhan terkait dengan meningkatnya kadar hormon promotor pertumbuhan (IAA, GA, total sitokinin) dan rendahnya kadar ABA. Peningkatan terbesar parameter tersebut terukur pada tanaman yang terkena berbagai kadar fenol terutama tanaman yang diperlakukan dengan asam benzoat. Efek seperti itu tergantung kadarnya. Semua perlakuan menyebabkan kenaikan signifikan dalam jumlah biji dan kandungan minyak atsiri. Selain itu, analisis Kromatografi Gas Cair mengungkapkan bahwa komponen utama yang teridentifikasi dari minyak atsiri adalah asam 2,2-dimetil butanoat, isobutil isobutirat, $\alpha$-isoforon, timol, fensil asetat dan linalool. Perlakuan fenolat dan asam amino mengakibatkan perbedaan kualitatif komponen minyak atsiri ini.
\end{abstract}

Kata kunci: Ammi visnaga, senyawa fenolat, asam amino, hormon, kriteria pertumbuhan, minyak atsiri

\section{INTRODUCTION}

Ammi visnaga, known as Khella, is an annual or perennial herb belongs to family Apiaceae (Umbelliferae). Khella is native to the Mediterranean and is cultivated in Egypt. Ammi visnaga is antiasthmatic, diuretic, lithontripic and vasodilator. It is an effective muscle relaxant and has been used for centuries to alleviate the excruciating pain of kidney stones (Chevallier 1996). The seeds used as a folk medicine for diuretic and lithontripic (Uphof 1959). Visnaga seeds contain oil that includes the substance 'khellin', which is used in the treatment of asthma. They have antispasmodic action on the smaller bronchial muscles, dilate the bronchial, urinary and blood vessels without affecting blood pressure (Bown 1995). Essential oil of $A$. visnaga is known for its proprieties against coronary diseases and bronchial asthma (Rose and Hulburd 1992; Satrani et al. 2004). The major components were linalool, isoamyl 2-methyl butyrate, and isopentyl isovalerate (Khadhri et al. 2011).

Furthermore, phenolics are low molecular compounds ubiquitous in all tissues of higher plants with great significance in plant development. Phenolic compounds are some of the most widespread molecules among plant secondary metabolites, and are of great significance in plant development (Curir et al. 1990). However, their biological, ecological and agronomical significance in the rhizosphere is much less clear. Furthermore, these biomolecules may contribute in soil and water conservation, weed management, mineral element nutrition, as well as the impact as signal molecule in certain symbiotic relationships, and act as defense molecules against soil 
pests and pathogens (Makoil and Ndakidemi 2007). Additionally, they serve as flower pigments, act as constitutive protection agents against biotic and abiotic stress (Deladonde et al 1996), function as signal molecules, act as allelopathic compounds, and affect cell and plant growth (Dakora 1995; Dakora and Phillips 1996; Ndakidemi and Dakora 2003), are important natural animal toxicants (Adams 1989) and some may function as pesticides (Vidhyasekaran 1988; Waterman and Mole 1989; Beier 1990). They are also functional components of the rhizosphere and its soil organic matter (Haider et al. 1975; Martin 1977). They have long been recognized as allelochemicals for weed control (Rice 1984; Putnam and Tang 1986) phytoestrogens in animals (Adams 1989) and plant defense molecules (Vidhyasekaran 1988). In the rhizosphere, they act as important precursors for the synthesis of soil humic substances (Haider et al. 1975). Salicylic acid participates in the regulation of several physiological processes in plant such as stomatal closure, nutrient uptake, chlorophyll synthesis, protein synthesis, inhibition of ethylene biosynthesis, transpiration and photosynthesis (Khan et al. 2003; Shakirova et al. 2003). SA increase cell metabolic rate (Amin et al. 2007). The biosynthesis of salicylic acid in plants starts from phenylalanine and follows one of two known paths of synthesis which involves trans-cinnamic acid then hydroxylation of benzoic acid which is a direct precursor of salicylic acid (Raskin 1992).

Moreover, amino acids as organic nitrogenous compounds are the building blocks in the synthesis of proteins (Davies 1982). Amino acids are particularly important for cell growth stimulation. They act as buffers which help to maintain favorable $\mathrm{pH}$ value within the plant cell. They protect the plants from ammonia toxicity. They can serve as a source of carbon and energy, as well as protect the plants against pathogens. Amino acids also function in the synthesis of other organic compounds, such as protein, amines, purines and pyrimidines, alkaloids, vitamins, enzymes, terpenoids and others (Goss 1973; Abd El-Aziz and Balbaa 2007). Furthermore, Hass (1975) stated that the biosyntheses of cinnamic acids (which are the starting materials for the synthesis of phenols are derived from phenylalanine and tyrosine.

The aim of this study is to investigate the role of some phenolic substances (salicylic acid, t-cinnamic acid and benzoic acid) and amino acids (tyrosine and phenylalanine) on the growth, endogenous hormones, photosynthetic pigments, total, soluble and insoluble carbohydrates of $A$. visnaga plants as well as the essential oil content of the seeds.

\section{MATERIALS AND METHODS}

\section{Experimental}

Two pot experiments were conducted in the greenhouse of National Research Centre (NRC), Dokki, Cairo, Egypt, during two successive seasons of 2009/2010 and 2010/2011. Ammi visnaga seeds were obtained from the Department of Medicinal and Aromatic Plants, Ministry of Agriculture, Giza, Egypt. Ten sterilized seeds were sown in each pot $(30 \mathrm{~cm}$ diameter $)$ in the third week of October.
Each pot was filled with $10 \mathrm{~kg}$ of air-dried clay soil. Physical and chemical properties of the soil used in this study were determined according to Jackson (1973) and Cottenie et al. (1982) and are presented in Table (1). Eight weeks after sowing, the seedlings were thinned and three plants per pot were left. Pots were divided into three main groups. The first group was exposed to different levels of phenolic compounds (salicylic acid, trans-cinnamic acid, and benzoic acid) at concentrations 5, 10 and $20 \mathrm{mg} \mathrm{L}^{-}$. The second group was sprayed with different levels of amino acids (phenylalanine and tyrosine) at concentrations 50,100 and $200 \mathrm{mg} \mathrm{L}^{-1}$. Phenolic compounds and amino acids were applied after 30 days from the sowing date. The third group was sprayed with $\mathrm{H}_{2} \mathrm{O}$ to serve as control. The experiments conducted under natural day conditions, with photoperiod $11 \mathrm{hrs} \pm 2$ and temperature about $27^{\circ} \mathrm{C} \pm 2$.

Table 1. Physical and chemical properties of the soil used

\begin{tabular}{llllllll}
\hline \multicolumn{1}{c}{$\begin{array}{c}\text { Soil } \\
\text { texture }\end{array}$} & pH & EC* & $\begin{array}{c}\text { Organi } \\
\text { c C }\end{array}$ & $\begin{array}{c}\text { Organic } \\
\text { matter }\end{array}$ & $\begin{array}{c}\text { Total } \\
\mathbf{N}\end{array}$ & $\begin{array}{c}\text { Total } \\
\mathbf{P}\end{array}$ & $\begin{array}{c}\text { Total } \\
\text { K }\end{array}$ \\
\cline { 3 - 7 } & & & & $(\%)$ \\
\hline $\begin{array}{l}\text { Sandy } \\
\text { loam }\end{array}$ & 7.2 & 0.6 & 0.9 & 1.9 & 0.3 & 0.1 & 0.1 \\
\hline
\end{tabular}

Note: EC $*=$ Electric conductivity (salinity)

All agricultural practices were conducted according to the recommendations by the Egyptian Ministry of Agriculture as follows: fertilizers were added to all pots as follows: cattle manure $\left(2 \mathrm{~g} \mathrm{pot}^{-1}\right)$, phosphorus $\left(2 \mathrm{~g}\right.$ pot $\left.{ }^{-1}\right)$ as calcium superphosphate $\left(15.5 \% \mathrm{P}_{2} \mathrm{O}_{5}\right)$, nitrogen $\left(2 \mathrm{~g} \mathrm{pot}^{-1}\right)$ as ammonium sulphate $(20.5 \% \mathrm{~N})$ and potassium $(1.5 \mathrm{~g}$ pot $\left.{ }^{-1}\right)$ as potassium sulphate $\left(48 \% \mathrm{~K}_{2} \mathrm{O}\right)$. Weeds were removed by hand and only natural pesticides were used for any plant diseases. The growth parameters of differently treated Ammi plants were measured after 75, 119, 180 and 210 days from sowing (stages $\mathrm{A}, \mathrm{B}, \mathrm{C}$, and $\mathrm{D}$ respectively). Stage A was at the vegetative growth while stage $\mathrm{B}$ at the beginning of flowering and stages $\mathrm{C}$ and $\mathrm{D}$ were at early fruiting and harvest time.

\section{Vegetative growth characters}

Plant height $(\mathrm{cm})$, fresh and dry weights of shoot $(\mathrm{g}$ plant $^{-1}$ ) were recorded during the vegetative stage. Plant height $(\mathrm{cm})$, number of branches and umbels (plant $\left.{ }^{1}\right)$, fresh and dry weights of shoots (plant- ${ }^{1}$ ) were recorded at flowering, early fruiting, and fruiting stages.

\section{Endogenous hormones}

The endogenous hormone levels were determined using the method described by Wasfy and Orrin (1975). Chlorophyll (chl) a, chl b and total carotenoids content was measured according to the method of Association of Official Agricultural Chemists (AOAC 1970).

\section{Total and soluble carbohydrate}

Total and soluble carbohydrate contents were determined according to the method described by Dubois et al. (1956). Then, the insoluble carbohydrates were calculated. 


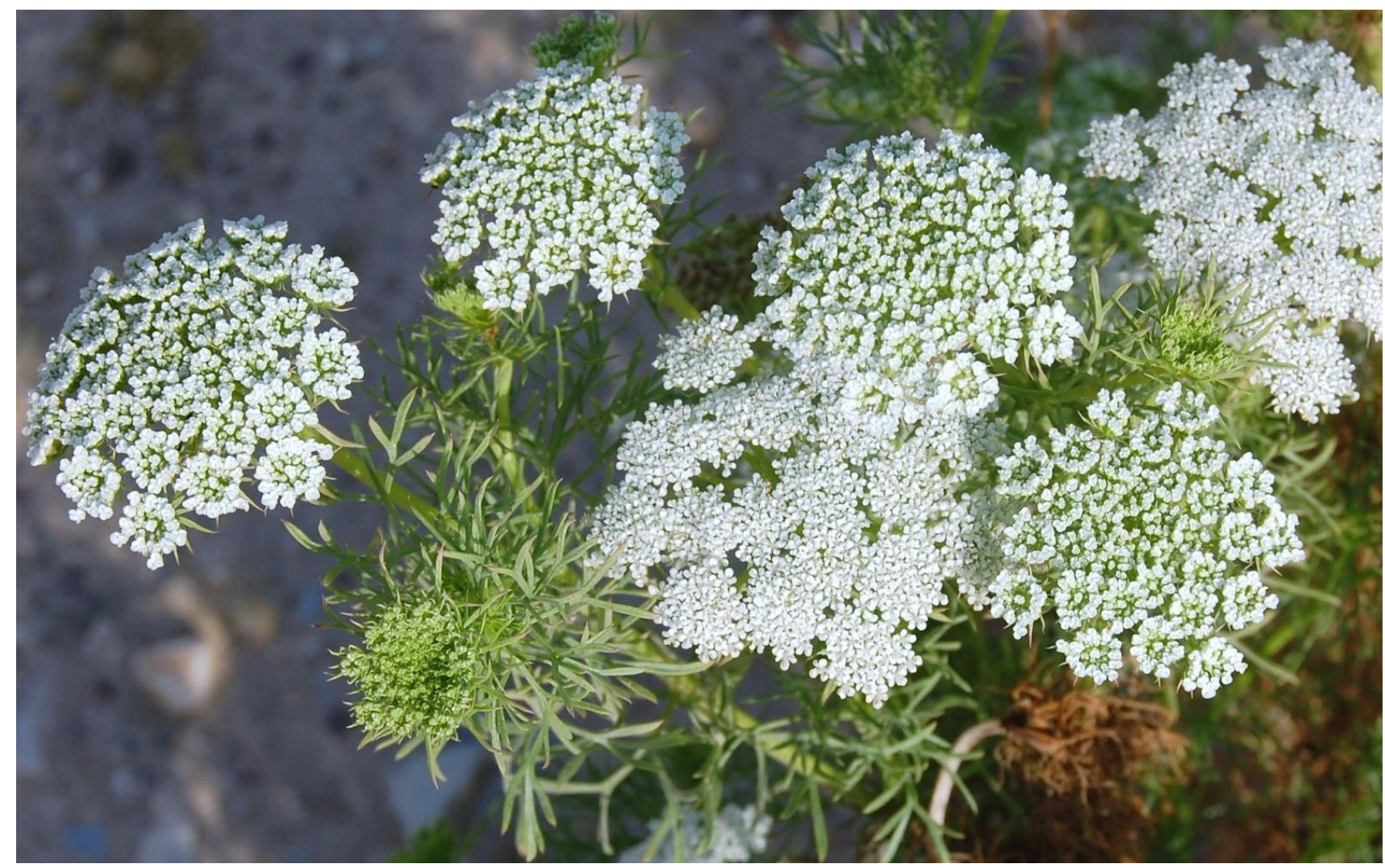

Figure 1. Ammi visnaga L. (Khella, bisnaga or toothpick weed)

\section{Essential oil isolation}

The ripening fruits of A. visnaga were collected air dried and weighed for extraction of the essential oil. Five grams of dry fruits were crushed into smaller pieces and reduced to fine powder with the aid of a mechanical grinder. The powder sample was extracted with petroleum ether (PE 40$60^{\circ} \mathrm{C}$ ) for $48 \mathrm{~h}$ at room temperature. The extract was evaporated to dryness using rotary evaporation at reduced pressure. The essential oil was passed over dark anhydrous sodium sulfate to remove moisture. The fraction obtained was stored in a refrigerator at $4^{\circ} \mathrm{C}$ in dark to identify the chemical constituents of oil (Adams 1995). GC-MS analysis was carried out on a Varina 3400 system equipped with a DB-5 fused silica column (30 m x $0.25 \mathrm{~mm}$ i.d.); Oven temperature was 40 to $240^{\circ} \mathrm{C}$ at a rate of $4{ }^{\circ} \mathrm{C} \mathrm{min}-1$, transfer line temperature $260^{\circ} \mathrm{C}$, injector temperature $250^{\circ} \mathrm{C}$, carrier gas helium with a linear velocity of $31.5 \mathrm{~cm}$ $\mathrm{s}^{-1}$, split ratio $1 / 60$, flow rate $1.1 \mathrm{~mL} \mathrm{~min}^{-1}$, Ionization energy $70 \mathrm{eV}$; scan time $1 \mathrm{~s}$; mass range 40-350 amu.

\section{Identification of components}

The components of the oil were identified by comparison of their mass spectra with those of a computer library or with authentic compounds and confirmed by comparison of their retention Indices with those of authentic compounds. Kovats indices (Kováts 1958) were determined by coinjection of the sample with a solution containing a homologous series of $n$-hydrocarbons, at a temperature run identical to that described above.

\section{Statistical analysis}

In this experiment, one factor was considered: different concentrations of amino acids (50, 100 and $\left.200 \mathrm{mg} \mathrm{L}^{-1}\right)$, phenolic compounds treatments $\left(5,10\right.$ and $\left.20 \mathrm{mg} \mathrm{L}^{-1}\right)$ and control. The experimental design followed a complete random block design. According to Sendecor and Cochran (1990), the average of data was statistically analyzed using 1-way analysis of variance (ANOVA-1). Significant values determined according to the Least Significant Difference (LSD at 0.05 and at $0.01 \mathrm{p}$ ) by using the STAT-ITCF program (1982).

\section{RESULTS AND DISCUSSION}

\section{Effect of amino acids and phenolic compounds on growth parameters}

Foliar application of different concentrations of either phenols or amino acids stimulate gradual increases in growth parameters in terms of plant height, number of branches, number of umbels fresh and dry weights and water content of A. visnaga shoot throughout the experimental periods. Results also, investigated that phenols stimulate all the previous morphological parameters, particularly at $20 \mathrm{mg} \mathrm{L}^{-1}$ compared with those of amino acids (tyrosine and phenylalanine) throughout the experimental period (Figures 1-6). The greatest increases in all investigated morphological criteria were measured in A. visnaga plants exposed to 20 $\mathrm{mg} \mathrm{L}^{-1}$ benzoic acid at all stages. Similar results were obtained by Balbaa and Talaat (2007) who concluded that phenyl- 
alanine treatments significantly promoted plant height, number of branches, fresh and dry weights of rosemary plants. Abd El-Aziz et al. (2007) also indicated that foliar application of tyrosine significantly promoted plant height, number of leaves and branches, fresh and dry weights of branches and shoots and stem diameter in both cuttings of Salvia farinacea plants. It was recorded that application of certain amino acids significantly increased the vegetative growth of Chrysanthemum (El-Fawakhry and El-Tayeb 2003), peppermint (Refaat and Naguib 1998), datura (Youssef et al. 2004) and Pelargonium graveolens (Mahgoub and Talaat 2005). Furthermore, salicylic acid caused significant increases in most growth parameters of different plant species (Abd El-Wahed et al. 2006; ElKhallal et al. 2009; Delavari et al. 2010; Dawood et al. 2012). The promotive effect of salicylic acid could be attributed to its bioregulator effects on physiological and biochemical processes in plants such as ion uptake, cell elongation, cell division, cell differentiation, sink/source regulation, enzymatic activities, protein synthesis and photosynthetic activity as well as increase the antioxidant capacity of plants (Raskin 1992; Blokhina et al. 2003; ElTayeb 2005).

\section{Effect of amino acids and phenolic compounds on chemical composition}

The changes of chlorophylls $a$ and $b$ as well as carotenoids content in response to amino acids and phenolics treatments are shown in Figure 7. High pigments levels (chl a, b, carotenoids) were measured in A. visnaga leaves treated with phenols compared with those of amino acids. The maximum increase in chlorophylls and carotenoids are recorded in leaves treated with $20 \mathrm{mg} \mathrm{L}^{-1}$ benzoic acid. The increments in pigment level were attributed to the promotion in its synthesis and/or retardation of pigment degradation. These results are similar to those obtained by Sharma et al. (1995) who found that excised leaves of Tropaeolum majus, treated with t-cinnamic acid, retained more chlorophyll $(60 \%$ higher at $10^{-3} \mathrm{M}$ ) compared to control. Moreover, the potent effects of particularly salicylic acid might be ascribed firstly to the reduction in chlorophyll loss due to its ability to increase the antioxidant capacity of the plants (Kuorzer et al. 1999) or inducing the synthesis of stabilizing substances (Nemeth et al. 2002). Salicylic acid caused significant increases in photosynthetic pigments (Figure 8). These results corroborate with those of Khodary (2004) and Gunes et al. (2005) on maize, El-Tayeb (2005) on barley, and Dawood et al. ( 2012) on sunflower.

The enhancing effects of SA on photosynthetic capacity could be attributed to its stimulatory effects on Rubisco activity and pigment contents (Khodary 2004) as well as increased $\mathrm{CO}_{2}$ assimilation, photosynthetic rate and increased mineral uptake by the plant (Szepesi et al. 2005). In addition, Arfan et al. (2007), pointed out that application of salicylic acid improved the photosynthetic capacity and retain pigment content through increasing IAA and Cytokinins, therefore, inhibits their senescence. Similar results were obtained by Hassanein (2003) on Foeniculum vulgare plants and Abou Dahab (2006) on Philodendron erubescens plant. They reported that foliar application of the amino acid (tryptophan) caused an increase in photosynthetic pigments contents.

The increments of the photosynthetic pigments in the treated A. visnaga leaves were concomitant with a gradual increase in total, soluble and insoluble carbohydrates (Figure 8). The maximum increases in soluble and insoluble carbohydrates were measured in the plants exposed to foliar application of phenolic compounds compared to those treated with amino acids. Moreover, such increments in the levels of total, soluble and insoluble carbohydrates were recorded in leaves exposed to $20 \mathrm{mg} \mathrm{L}^{-}$ ${ }^{1}$ benzoic acid. These results are in agreement with those obtained by Goss (1973), who indicated that amino acids can serve as a source of carbon and energy when carbohydrates become deficient in the plant; amino acids are determinate, releasing the ammonia and organic acid from which the amino acid was originally formed. The organic acids then enter the Kreb's cycle, to be broken down to release energy through respiration. These results could also be explained by the findings obtained by Gamal El-Din et al. (1997) who found that treatment of lemongrass plants with $100 \mathrm{ppm}$ phenylalanine in the first cut and ornithine in the second cut recorded the highest level of carbohydrate percentage compared with control. Refaat and Naguib (1998) reported that application of all amino acids (alanine, cytosine, guanine, thiamine, and Ltyrosine) increased the total carbohydrates percentage in peppermint leaves. The effect of the amino acids on the total carbohydrates content may be due to their important role on the biosynthesis of chlorophyll molecules which in turn affected carbohydrate metabolism. In this respect, Talaat and Balbaa (2010) reported that chemical analysis of the leaves of sweet basil indicated that the contents of total soluble and total carbohydrates were significantly increased as a result of foliar application of trans-cinnamic acid. Tari et al. (2002) and Dawood et al. (2012) reported that salicylic acid application resulted in a significant increase in total soluble carbohydrates content in leaves of tomato and sunflower, thus maintaining the carbohydrates pool in the chloroplasts at a high level.

Plant hormones play an important role in development processes; some of them have a key in the most plant mechanisms. Data represented in Figure 9 showed increments in gibberellins $\left(\mathrm{GA}_{3}\right)$, indole acetic acid (IAA) and cytokinins $(\mathrm{Z} \& \mathrm{ZR})$ in plants treated with amino acids and phenolic compounds. High concentrations of gibberellins $\left(\mathrm{GA}_{3}\right)$, Indole acetic acid (IAA) and cytokinins ( $\mathrm{Z} \& \mathrm{ZR}$ ) were measured in A. visnaga leaves treated with phenolic compounds compared with amino acids. The highest values of $\mathrm{GA}_{3}$, IAA and cytokinins were recorded in plants exposed to $20 \mathrm{mg} \mathrm{L}^{-1}$ benzoic acid. A reduction in abscisic acid (ABA) level was concomitant with such increments in growth promoters estimated in plants exposed to either phenolic compounds or amino acids. The increases in the levels of endogenous growth promoters could be attributed to the increase in their biosynthesis and/or decrease in their degradation and conjugation. On the other hand, the reduction in ABA level could be due to the shift of the common precursor isopentenyl pyrophosphate 

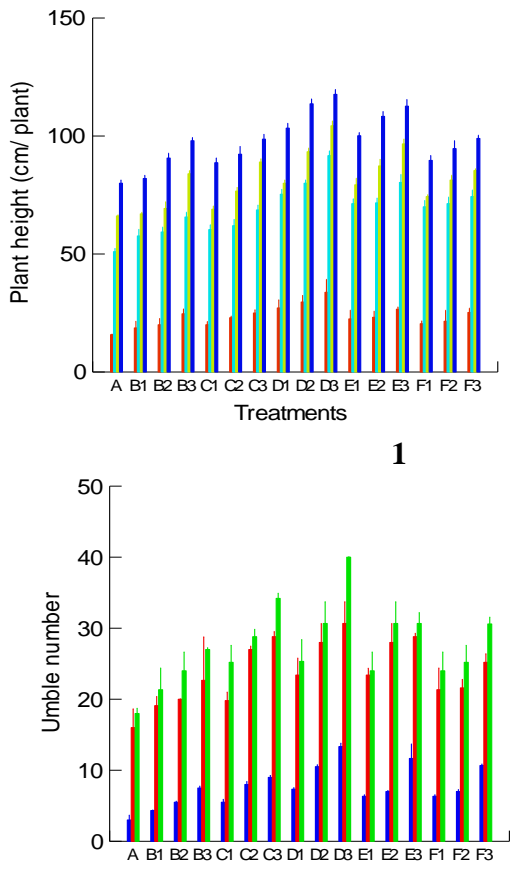

Treatments
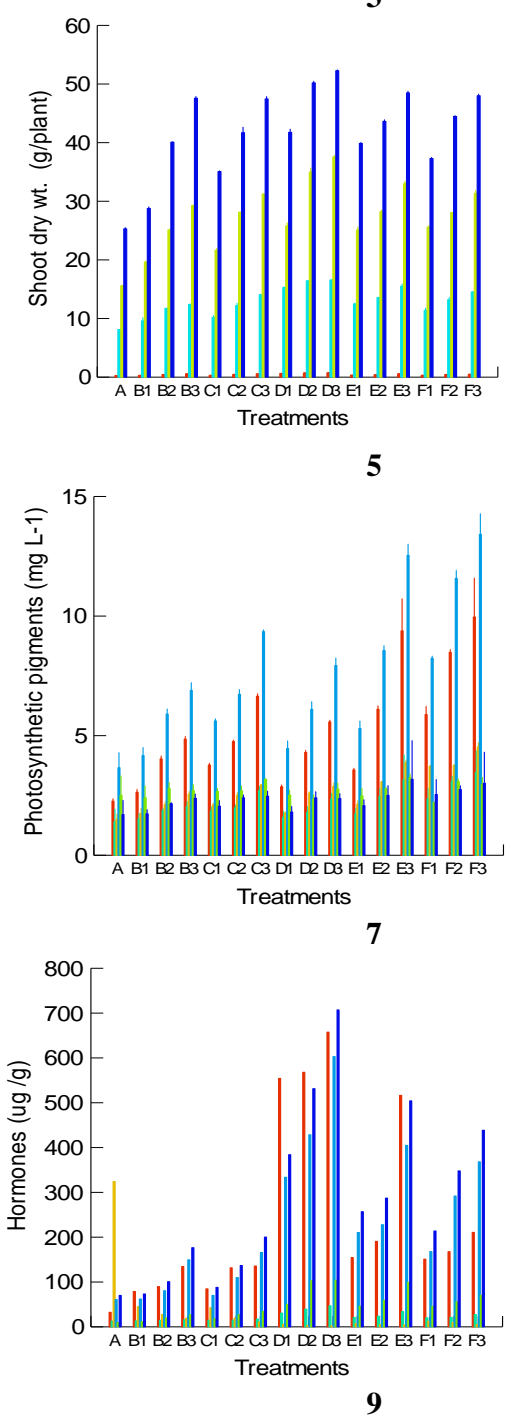

Stages

- FFruiting

EEarly fruiting

- FFlowering

Stages

- Fruiting

- Early fruiting

- Flowering

Stages

- Fruiting

- Early fruiting

- Flowering

- Vegetative

- IChl a+Chl b/Carotenoids

- $\mathrm{IChla} \mathrm{a} / \mathrm{Chl} b$

- IChl a+Chl b

- Carotenoids

- Chl b

- 'Chl a

- Cytokinins

- $\mathrm{iZR}$

- $2 \mathrm{Z}$

- IIAA

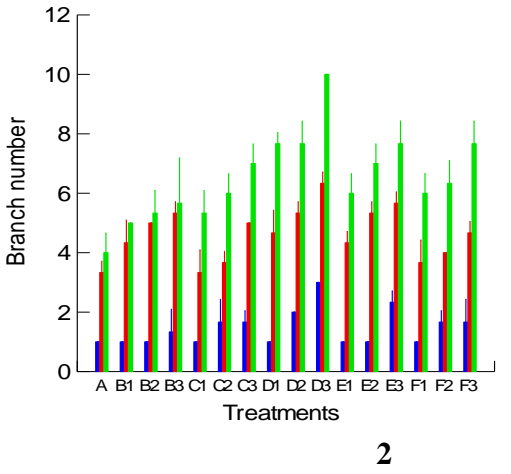

Stages

- FFruiting

- EEarly fruiting

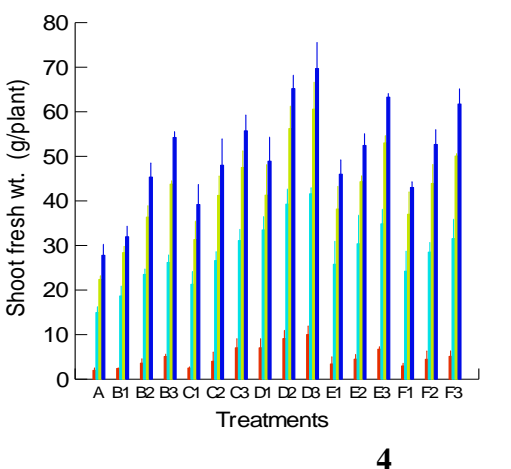

Stages

- IFruiting

|Early fruitin
|Flowering

- Vegetative

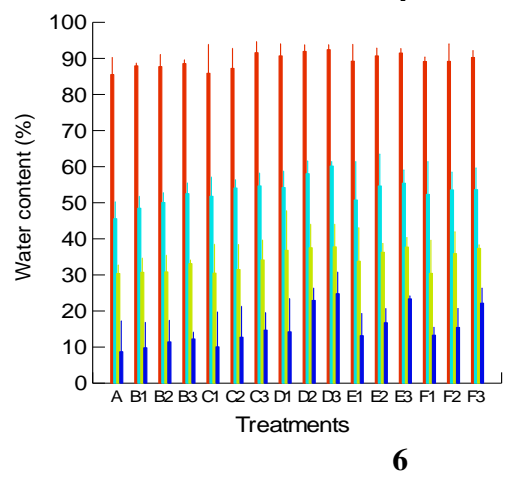

Stages

- Fruiting

- Early fruiting

- Vegetative

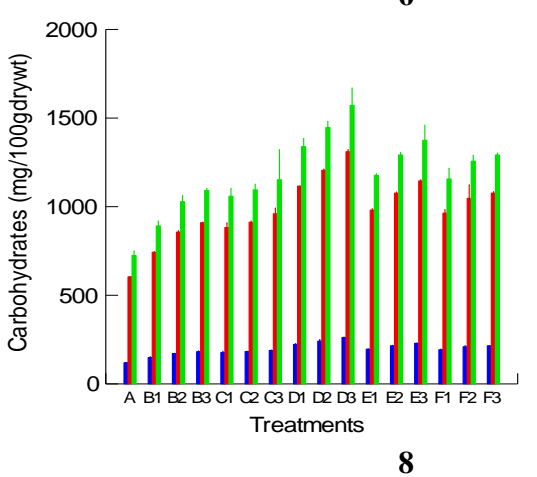

- Total carbohydrate

- Insoluble carbohydrate

- Soluble carbohydrate

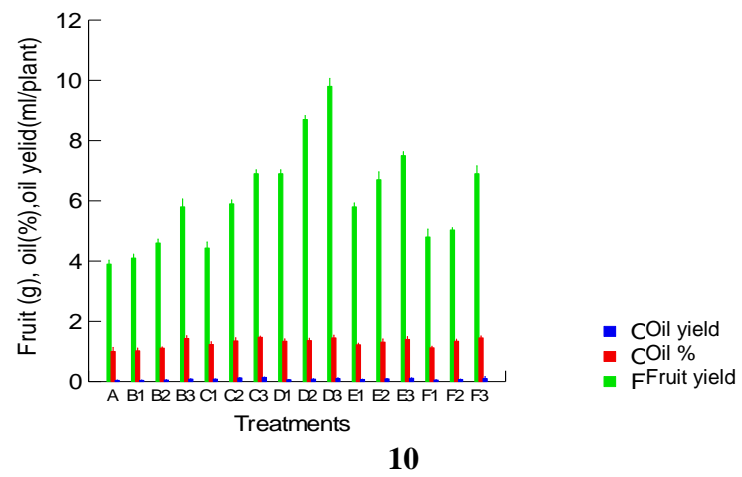


Figure 1. Changes in the values of plant height of shoot system of $A$. visnaga plants $\left(\mathrm{cm} \mathrm{plant}^{-1}\right)$ treated with different concentrations of amino acids and phenolic compounds during the vegetative, flowering, early fruiting and fruiting stages, each value is mean of ten replicates \pm SD

Figure 2. Changes in the values of branch number of shoot system of A. visnaga plants treated with different concentrations of amino acids and phenolic compounds during the flowering, early fruiting, and fruiting stages, each value is mean of ten replicates \pm SD

Figure 3. Changes in the values of umbels number of shoot system of A. visnaga plants treated with different concentrations of amino acids and phenolic compounds during the flowering, early fruiting, and fruiting stages, each value is mean of ten replicates \pm SD

Figure 4. Changes in the values of fresh weight of shoot system of A. visnaga plants ( $\mathrm{g} \mathrm{plant}^{-1}$ ) treated with different concentrations of amino acids and phenolic compounds during the vegetative, flowering, early fruiting and fruiting stages, each value is mean of ten replicates $\pm \mathrm{SD}$

Figure 5. Changes in the values of dry weight of shoot system of $A$. visnaga plants $\left(\mathrm{g} \mathrm{plant}^{-1}\right)$ treated with different concentrations of amino acids and phenolic compounds during the vegetative, flowering, early fruiting and fruiting stages, each value is mean of ten replicates $\pm \mathrm{SD}$

Figure 6. Changes in the percentage of water content of A. visnaga shoots treated with different concentrations of amino acids and phenolic compounds during the vegetative, flowering, early fruiting and fruiting stages, each value is mean of ten replicates \pm SD

Figure 7. Changes in the values photosynthetic pigments of $A$. visnaga plants $\left(\mathrm{mg} \mathrm{L}^{-1}\right)$ treated with different concentrations of amino acids and phenolic compounds during the vegetative stage, each value is mean of ten replicates \pm SD

Figure 8. Changes in the percentage of total, soluble and insoluble carbohydrates of A. visnaga plants (\%) treated with different concentrations of amino acids and phenolic compounds during the vegetative stage; each value is mean of ten replicates \pm SD

Figure 9. Changes in the values of phytohormone contents of $A$. visnaga Plants $\left(\mu \mathrm{g} \mathrm{g}^{-1}\right)$ treated with different concentrations of amino acids and phenolic compounds during the vegetative stage

Figure 10. Changes in the values of fruit yield $(\mathrm{g})$, oil percentage $(\%)$ and oil yield $\left(\mathrm{ml} \mathrm{plant}^{-1}\right)$ of A. visnaga plants treated with different concentrations of amino acids and phenolic compounds, each value is mean of ten replicates \pm SD

Table 2. The constituents of essential oil of A. visnaga plants

\begin{tabular}{|c|c|c|c|c|c|c|c|c|c|c|c|c|c|c|c|c|c|c|}
\hline \multirow{3}{*}{ No. } & \multirow{3}{*}{ Components (\%) } & \multirow{3}{*}{ KI } & \multicolumn{16}{|c|}{ Treatments (ppm) } \\
\hline & & & \multirow[t]{2}{*}{$\mathbf{0}$} & \multicolumn{3}{|c|}{ Tyrosine } & \multicolumn{3}{|c|}{ Phenylalanine } & \multicolumn{3}{|c|}{ Benzoic acid } & \multicolumn{3}{|c|}{ Trans-cinnamic acid } & \multicolumn{3}{|c|}{ Salicylic acid } \\
\hline & & & & 50 & 100 & 200 & 50 & 100 & 200 & 5 & 10 & 20 & 5 & 10 & 20 & 5 & 10 & 20 \\
\hline 1 & $\alpha$-Thuje & 31 & - & 2.5 & 1.3 & 1.0 & 1.2 & 1.9 & - & 1.1 & - & 3.9 & 2.2 & 0.4 & 0.9 & 1.5 & 1.2 & 3.9 \\
\hline 2 & Myrcene & 91 & - & 2.0 & 0.4 & 8.0 & 3.6 & 3.6 & - & 1.2 & - & 3.7 & 1.9 & 0.4 & 1.6 & 2.1 & 1.4 & 4.9 \\
\hline 3 & Isobutyl isobutyrate & 1004 & 22.9 & 20.6 & 35.3 & 15.9 & 18.9 & 18.6 & 24.1 & 14.8 & 24.3 & 9.9 & 11.4 & 24.4 & 22.6 & 6.4 & 16.5 & 15.6 \\
\hline 4 & Linalool & 1029 & 5.7 & 2.9 & 0.6 & 1.3 & 3.3 & 1.3 & - & 0.8 & - & 4.5 & 2.1 & 0.3 & 1.1 & 1.1 & 2.5 & 2.6 \\
\hline 5 & 2,2-Di & 1108 & 28.9 & 35.4 & 55.4 & 30.4 & 20.6 & 38.8 & 50.5 & 35.0 & 25.9 & 21.1 & 27.4 & 36.5 & 34.6 & 59.0 & 34.4 & 38.2 \\
\hline 6 & $\alpha$-Isop & 1121 & 13.4 & 17.9 & 0.9 & 3.0 & 2.7 & 1.2 & 9.2 & 11.9 & 16.7 & 9.6 & 13.8 & 19.3 & 21.1 & 6.4 & 11.3 & 13.8 \\
\hline 7 & Fenc & 1220 & 6.3 & 3.8 & 0.3 & 2.5 & 7.8 & 5.0 & - & 1.0 & - & 4.8 & 7.0 & 0.2 & 3.2 & 3.7 & 4.7 & 3.5 \\
\hline 8 & Borr & 1289 & - & 1.7 & 0.4 & 7.8 & 2.6 & 5.1 & - & 0.8 & - & 4.3 & 5.3 & 0 . & 2 & 0.9 & 0.8 & 2.0 \\
\hline 9 & Thyl & 0 & 13.2 & 8.5 & 1.8 & 13.1 & 9.3 & 2.8 & - & 2.1 & 15.2 & 7.0 & 8.0 & & 1 & 6.7 & 3.7 & 5.7 \\
\hline 10 & Gera & 381 & - & - & 0.3 & 1.4 & 4.9 & 2.6 & 9.1 & 11.5 & - & 5.2 & 3.8 & 11.2 & 2. & 0.9 & 6.9 & 4.5 \\
\hline 11 & Lav & 1439 & - & - & 0.2 & 0.7 & 7.6 & 3. & - & 1.4 & - & 3.7 & 2.7 & & 1. & 2.2 & 0.9 & 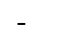 \\
\hline 12 & Citr & 6 & - & - & 0.6 & 5.6 & 7.9 & 3. & - & 1.0 & - & 5.3 & 1.6 & & 1. & 3.1 & 2.4 & - \\
\hline 13 & Crov & 0 & 9.6 & 4.7 & 1. & 6.7 & 8.1 & 11.0 & 7.1 & 10.4 & 15.0 & 5.9 & 7.2 & & 3 & 6.0 & 8.7 & 5.3 \\
\hline 14 & $\alpha-D a$ & & - & - & 0. & 1.5 & 2.1 & 1. & - & 3.2 & 2.9 & 5.7 & 2.7 & & 0 & - & 2.2 & - \\
\hline 15 & $(\mathrm{Z}, \mathrm{E})$ & 1701 & - & - & 0 . & 1.1 & 1.4 & 0 . & - & 3.8 & - & 5. & 2.9 & & & - & 2.4 & - \\
\hline \multicolumn{2}{|c|}{ Total identified } & & 100 & 100 & 100 & 82.6 & 100 & 10 & 100 & 100 & 100 & 100 & 100 & & 1 & 100 & 100 & 100 \\
\hline \multicolumn{2}{|r|}{ Monoterpene compounds } & & 100 & 100 & 99.4 & 98.9 & 98.6 & 99.2 & 100 & 96.2 & 100 & 94.6 & 97.1 & 99.9 & 98.3 & 100 & 97.6 & 100 \\
\hline \multicolumn{2}{|c|}{ Sesquiterpene compounds } & & - & - & 0.6 & 1.1 & 1.4 & 0.8 & - & 3.8 & - & 5.4 & 2.9 & 0.1 & 1.7 & - & 2.4 & - \\
\hline
\end{tabular}

to biosynthesis of cytokinins and/or gibberellins instead of ABA (Hopkins and Huner 2004). These results are in accordance with those obtained by Shehata et al. (2000), Shehata et al. (2001) and Zaghlool (2002). The increases in IAA and $\mathrm{GA}_{3}$ in shoot tissues of sunflower plant concurrently with the increase in growth rate due to the role of these endogenous hormones in stimulating cell division and/or the cell enlargement and subsequently growth (Taiz and Zeiger 1998). It is well known that salicylic acid induces flowering, increases flower life, retard senescence and increases cell metabolic rate. In addition, salicylic acid may be a prerequisite for synthesis of auxin and /or cytokinin. (Metwally et al. 2003; Gharib 2006). Furthermore, these increments in growth regulating substances might be a prerequisite for acceleration of growth resumption of sunflower plant. In addition, salicylic acid effects on abscisic acid (Senaratna et al. 2000), gibberellins (Traw and Bergelson 2003) regulate many 
physiological processes and plant growth. Moreover, Dawood et al. (2012) reported that SA caused marked increments in IAA, $\mathrm{GA}_{3}$, zeatin and zeatin riboside, in the meantime decrease in ABA content comparing with untreated controls.

Figure 10 indicated that the fruit yield, oil yield percentage and oil yield $\left(\mathrm{ml} \mathrm{plant}^{-1}\right)$ increased in plants treated with phenolic compounds and amino acids. The maximum levels of oil yield percentage $\left(\mathrm{ml} \mathrm{plant}^{-1}\right)$ were recorded in seeds exposed to $20 \mathrm{mg} \mathrm{L}^{-1}$ benzoic acid. The increment in oil\% and protein $\%$ might be due to the increase in vegetative growth and nutrients uptake. Similar results were reported by Gharib (2006) and Çag et al. (2009). In addition, Noreen and Ashraf (2010) mentioned that high doses of salicylic acid caused marked increases in sunflower achene oil content as well as some key fatty acids and significant decrease in stearic acid.

Table 2 represents the compounds of essential oil obtained from $A$. visnaga as detected by GC-MS. the relative levels of various constituents of oil yield were increased, decreased or disappeared in A. visnaga fruits of plants treated with amino acids and phenolic compounds compared with untreated control plants. 2,2dimethylbutanoic acid, isobutyl isobutyrate, linalool, thymol, and croweacin are the major constituents of $A$. visnaga fruits. These results are similar to those obtained by Khalfallah et al. (2011) who found that the major component of essential oil in A. visnaga are 2, 2dimethylbutanoic acid, isobutyl isobutyrate, croweacin, linalool, and thymol. The effect of different treatments on essential oil and its constituents may be due to its effect on enzyme activity and metabolism of essential oil production (Burbott and Loomis 1969).

SA has a role in controlling gene expression (He et al. 2005) reported that most of the genes regulated by SA are defense-related genes and many of them participate in plant responses to biotic and abiotic stresses. Therefore SA may change secondary metabolites and its pathway by effects on plastid, chlorophyll level and represent stress conditions. The SA like stress manipulated quality and quantity of essential oil of Salvia macrosiphon. The yield of essential oil was increased. The useful component such as Linalool was increased. Seventeen components were identified in SA-treated plants (Rowshan et al. 2010).

\section{CONCLUSION}

Finally, it is apparently clear that phenolics treatments were more effective in enhancing growth and productivity of A. visnaga. Moreover, the greatest increase in the growth parameters and chemical constituents obtained at $20 \mathrm{mg} \mathrm{L}^{-1}$ of benzoic acid. On the other hand, the major component of essential oil gave the best percentage (59\%) was assayed in seeds exposed to salicylic acid.

\section{REFERENCES}

Abd El-Aziz NG, Balbaa LK. 2007. Influence of Tyrosine and Zinc on Growth, Flowering and Chemical Constituents of Salvia farinacea Plants. J Appl Sci Res 3 (11): 1479-1489.

Abd El-Wahed MSA, Amin AA, Rashad El-Sh M. 2006. Physiological effect of some bioregulators on vegetative growth, yield and chemical constituents of yellow maize plants. World J Agric Sci 2 (2): 149-155.

Abou Dahab TAM, Abd El-Aziz NG. 2006. Physiological effect of diphenylamine and tryptophan on the growth and chemical constituent of Philodendron erubescens plants.World J Agric Sci 2 (1): 75-81.

Adams NR. 1989. Phytoestrogens. In: Cheeke PR (ed). Toxicants of plants Origin, Vol. 4, Phenolics. CRC Press, Boka Raton, FL.

Adams R 1995. Identification of Essential Oil Components by Gas Chromatography/Mass Spectroscopy. Allured Publishing Co, Illinois.

Amin AA, Rashad M, El-Abagy HMH. 2007. Physiological effect of indole-3-butyric acid and salicylic acid on growth, yield and chemical constituents of onion plants. J Appl Sci Res 3: 1554-1563.

AOAC [Association of Official Agricultural Chemistry]. 1970. Official Methods Analysis. AOAC, Washington, DC., USA.

Arfan MH, Athar R, Ashraf M. 2007. Does exogenous application of salicylic acid through the rooting medium modulate growth and photosynthetic capacity in two differently adapted spring wheat cultivars under salt stress. J Plant Physiol 6 (4): 685-694.

Balbaa LK, Talaat IM. 2007. Physiological response of rosemary plants (Rosmarinus officinalis L.) to ascorbic acid, phenylalanine, and ornithine. Egypt J Appl Sci;22(11B): 375-385.

Beier RC. 1990. Natural pesticides and bioactive compounds in foods. Rev Environ Contam Toxicol 113: 47-137.

Blokhina O, Virolainen E, Fagerstedt KV. 2003. Antioxidants, oxidative damage and oxygen deprivations stress. (A review) Ann Bot 91: 179194.

Bown D. 1995. Encyclopaedia of Herbs and their Uses. Dorling Kindersley, London.

Burbott AJ, Loomis D. 1969. Evidence for metabolic turnover monoterpene in peppermint. Plant Physiol 44: 173-179.

Çag S, Gul CC, Sarsag M, Goren-Saglam N. 2009. Effect of salicylic acid on pigment, protein content and peroxidase activity in excised sunflower cotyledons. Pak J Bot 41(5): 2297-2303.

Chevallier A. 1996. The Encyclopedia of Medicinal Plants. Dorling Kindersley. London.

Cottenie A, Verloo M, Kiekens L, Velghe G, Camerlynck R. 1982. Chemical Analysis of Plant and Soil. Laboratory of Analytical and Agrochemistry, State Univ., Ghent, Belgium.

Curir PV, Sumere CF, Termini A, Barthe P, Marchesini A, Dolci M, 1990. Flavonoid accumulation is correlated with adventitious roots formation in Eucalyptus gunnii Hook micro propagated through axillary bud stimulation. Plant Physiol 92: 1148-1153.

Dakora FD, Phillips DA. 1996. Diverse functions of isoflavonoids in legumes transcend ant-microbial definitions of phytoalexins. Phys Mol Plant Path 49: 1-20.

Dakora FD. 1995. Plant flavonoids: Biological molecules for useful exploitation. Aust J Plant Phys 22: 87-99.

Davies DD. 1982. Physiological aspects of protein turn over. In: Boulter D, Partheir B (eds). Encycl Plant Physiol New Series, 14 A (Nucleic acids and proteins: structure biochemistry and physiology of proteins). Springer, Berlin.

Dawood MG, Sadak MS, Hozayen M. 2012. Physiological role of salicylic acid in improving performance, yield and some biochemical aspects of sunflower plant grown under newly reclaimed sandy soil. Aust J Bas Appl Sci 6 (4): 82-89.

Deladonde M, Barret Y, Coumans MP. 1996. Development of phenolic compounds in maize anthers (Zea mays) during cold pre-treatment prior to endogenesis. J Plant Physiol 149: 612-616.

Delavari PM, Baghizadeh A, Enteshari SH, Kalantari KhM, Yazdanpanah A, Mousavi EA. 2010. The effects of salicylic acid on some of biochemical and morphological characteristic of Ocimum basilicum under salinity stress. Austr J Basic and Applied Sci 4(10): 4832-4845.

Dubois M, Gilles KA, Hamilton JK, Roberts PA, Smith F. 1956. Phenol sulphuric acid method for carbohydrate determination. Ann Chem 28: 350-359.

El-Fawakhry FM, El-Tayeb HF. 2003. Effect of some amino acids and vitamins on chrysanthemum production. J Agric Res Alex Univ 8 (4): 755-766. 
El-Khallal SM, Hathout TA, Abd El Raheim A, Ashour A, Kerrit AA. 2009. Brassinolide and salicylic acid-induced growth, biochemical activities and productivity of maize plants grown under salt stress. Res J Agric Biol Sci 5 (4): 380-390.

El-Tayeb MA. 2005. Response of barley grains to the interactive effects of salinity and salicylic acid. Plant Growth Regul 45: 215-224.

Foucart T. 1982. Analyse factorielle, programmatiol sur micro-ordinateur. Masson, ITCF, Paris. [France]

Gamal El-Din KM, Tarraf SA, Balbaa LK. 1997. Physiological studies on the effect of some amino acids and microelements on growth and essential oil content in lemongrass (Cymbopogon citrates Hort. ). J Agric Sci Mansoura Univ 22 (12): 4229-4241.

Gharib FA. 2006. Effect of salicylic acid on the growth, metabolic activities and oil content of basil and marjoram. Int J Agric Biol 8 (4): 485-492.

Goss JA. 1973. Amino acid synthesis and metabolism physiology of plants and their cell. P. 202. Pergamon Press, New York.

Gunes A, Inal A, Alpaslan M, Cicek N, Guneri E, Eraslan F, Guzelordu T. 2005. Effects of exogenously applied salicylic acid on the induction of multiple stress tolerance and mineral nutrition in maize (Zea mays L.) Arch Agron Soil Sci 51: 687-695.

Haider K, Martin JP, Filip Z. 1975. Humus biochemistry. In: Paul EA (ed) Soil Biochemistry, Vol. 4, Marcel Dekker, New York.

Hass D. 1975. Molecular biochemical and physiological fundamentals of metabolism and development. In: Plant Physiology. Springer Verlag, Berlin.

Hassanein RAM. 2003. Effect of some amino acids,trace elements and irradiation on fennel (Foeniculum Vulgare L.) [Ph.D. Dissertation] Fac Agric Cairo Univ., Cairo.

He Y, Liu, Y, Cao W, Huai M, Xu B, Huang B. 2005. Effects of Salicylic acid on heat tolerance associated with antioxidant metabolism in Kentucky bluegrass. Crop Sci 45: 988-998.

Hopkins WG, Huner NPA. 2004. Introduction to plant physiology. $3^{\text {rd }}$ ed. John Wiley and Sons, New York.

Jackson ML. 1973. Soil Chemical Analysis. Prentice Hall Indian Private Limited, New Delhi.

Khadhri A, El Mokni R, Mguis K, Ouerfelli I, Eduarda MMA. 2011. Variability of two essential oils of Ammi visnaga (L.) Lam. a traditional Tunisian medicinal plant. J Med Plants Res 5 (2): 5079 5082.

Khalfallah A, Labed A, Semra Z, Alkaki B, Kabouche A, Touzani R, Kabouche Z. 2011. Antibacterial activity and chemical composition of the essential oil of Ammi visnaga L. (Apiaceae) from Constantine, Algria. Int J Med Arom Plants 1 (3): 302-305.

Khan W, Prithiviraj B, Smith DL. 2003. Photosynthetic responses of corn and soybean to foliar application of salicylates. J Pl Physiol 160: 485492.

Khodary SEA. 2004. Effect of salicylic acid on the growth, photosynthesis and carbohydrate metabolism in salt-stressed maize plants. Intl $J$ Agric Biol 6 1): 5-8.

Kováts E. 1958. 206. Gas-chromatographische charakterisierung organis verbindungen. Teil 1: Retentions indices aliphatischer halogenide, alkohole, aldehyde und ketone. Helv Chim Acta 41: 1915-1932.

Mahgoub MH, Talaat IM. 2005. Physiological response of rose geranium (Pelargonium graveolens, L.) to phenylalanine and nicotinic acid Ann Agric Sci Moshtohor 43 (2): 807-822.

Makoi JHJR, Ndakidemi PA. 2007. Biological, ecological and agronomic significance of plant phenolic compounds in rhizosphere of the symbiotic legumes. Afr J Biotech 6 (12): 1358-1368.

Metwally A, Finkemeier I, Georgi M, Dietz KJ. 2003. Salicylic acid alleviates the cadmium toxicity in barley seedlings. Plant Physiol 132: 272-281.

Ndakidemi PA, Dakora FD. 2003. Legume seed flavonoids and nitrogenous metabolites as signals and protectants in early seedling development. Review Fun Plant Biol 30: 729-745.

Németh M, Janda T, Horváth E, Páldi E, Szalai G. 2008. Environmental and experimental botany. Plant Sci 64: 105-112.

Noreen S, Ashraf M. 2010. Modulation of salt $(\mathrm{NaCl})$ induced effects on oil composition and fatty acid profile of sunflower (Helianthus annuus L.) by exogenous application of salicylic acid. J Sci Food Agric 90 (15): 2608-2616.

Putnam AR, Tang C. 1986. The science of allelopathy. Wiley, New York.

Raskin I. 1992. Role of salicylic acid in plants. Ann Rev Plant Physiol Plant Mol Biol 2: 439-463.
Raskin I. 1992. Role of salicylic acid in plants. Ann Rev Plant Phys Plant Mol Biol 2: 439-463.

Refaat AM, Naguib NY. 1998. Peppermint yield and oil quality as affected by application of some amino acids. Bull Fac Agric Cairo Univ 49: 89-98

Rice EL. 1984. Allelopathy. 2nd ed. Academic, Orlando, Fl.

Rose J, Hulburd J. 1992. The aromatherapy book applications and inhalations, North Atlantic Books, Berkeley, CA

Rowshan V, Khosh KM, Javidnia K. 2010. Effects of Salicylic Acid on Quality and Quantity of Essential oil Components in Salvia macrosiphon. J Biol Environ Sci 4 (11): 77-82.

Satrani B, Farah A, Fechtal M, Talbi M, Bouamri ML. 2004. Chemical composition and antimicrobial and antifungal activities of the essential oil of Ammi visnaga (L.) Lam from Marocco. Acta Bot Gal 151(1): 65-71

Senaratna T, Touchell D, Bunn T, Dixon K. 2000. Acetylsalicylic acid (aspirin) and salicylic acid induce multiple stress tolerance in bean and tomato plants. Plant Growth Regul 30: 157-161.

Shakirova FM, Sakhabutdinova AR, Bezrukova MV, Fathudinova RA, Fathutdinova DR. 2003. Changes in hormonal status of wheat seedlings induced by Salicylic acid and salinity. Plant Sci 164: 317322.

Sharma SS, Charan B, Rai VK. 1995. Influence of abscisic acid and transcinnamic acid on senescence of detached Tropaeolum majus leaves in relation to stomatal movements. J Plant Physiol 146: 751-753.

Shehata SAM, Ibrahim SI, Zaghlool AM. 2001. Physiological response of flag leaf and ears of maize plant induced by foliar application of kinetin (Kin) and salicylic acid (SA). Ann Agric Sci Ain Shams Univ Cairo 46 (2): 435-449.

Shehata SAM, Saeed MA, Abou El-Nour MS. 2000. Physiological response of cotton plant to the foliar spray with salicylic acid. Ann Agric Sci Ain Shams Univ Cairo 45 (1): 1-18.

Snedecor GW, Cochran WG. 1990. Statistical Methods, 11th ed. Iowa State Univ. Press, Ames, Iowa, USA.

Szepesi A, Cciszar J, Bajkan S, Gemes K, Horvath F, Erdei L, Deer AK, Simon ML, Tari I. 2005. Role of salicylic acid pre-treatment on the acclimation of tomato plants to salt and osmotic stress. Acta Biol Szeged 49: 123-125.

Taiz L, Zeiger E. 1998. Plant Physiology Sinaur Associates Inc. Publishers Sunderland, Massachetts, USA.

Takahama U, Oniki T. 1992. Regulation of peroxidase-dependent oxidation of phenols in the apoplast of spinach leaves by ascorbate. Plant Cell Phys 33: 379-387.

Talaat IM, Balbaa LK. 2010. Physiological response of sweet basil (Ocimum basilicum L.) to putrescine and trans-cinnamic acid. Amer Eur J Agric Environ Sci 8: 438-445.

Talaat IM, Youssef AA. 2002. The role of the amino acids lysine and ornithine in growth and chemical constituents of Basil plant. Egypt $\mathbf{J}$ App Sci 17 (5): 83-95

Tari I, Csizar J, Szalai G, Horvath F, Pecsvaradi A, Kiss G, Szepesi A, Szabo M, Laszlo E. 2002. Acclimation of tomato plants to salinity stress after salicylic acid pre-treatment. Acta Biol Szeged 46: 55-56.

Towers GHN, Abeysekera B. 1984. Cell wall hydroxycinnamate esters as UV-A receptors in phototropic responses of higher plants-a new hypothesis. Phytochem 23 (5): 951-952.

Traw MB, Bergelson J. 2003. Interactive effects of jasmonic acid, salicylic acid, and gibberellin on induction of trichomes in Arabidopsis. Am Soc Plant Bio 133: 1367-1375.

Uphof JCTh. 1959. Dictionary of Economic Plants. H.R. Engelman, Weinheim

Vidhyasekaran P. 1988. Physiology of disease resistance in plants, Vol. 1, CRC Press, Boca Raton, FL.

Wasfy WS, Orrin ES. 1975. Identification of plant hormones from cotton ovules. Plant Physiol 55: 550-554.

Waterman PG, Mole S. 1989. Extrinsic factors influencing production of metabolites in plants. In: Bernays EA (eds). Insect-Plant Interactions. CRC Press, Boca Raton, FL.

Youssef AA, El-Mergawi RA, Abd El-Wahed MSA. 2004. Effect of putrescine and phenylalanine on growth and alkaloid production of some Datura species. J Agric Sci Mansoura Univ 29: 4037-3053.

Zaghlool SAM. 2002. The effect of gibberellic acid $\left(\mathrm{GA}_{3}\right)$, salicylic acid (SA), spermidine (Spd) and methods of application on growth, yield, some chemical constituents and some phytohormones in mungbean (Vigna radiata L.). Arab Univ J Agric Sci Ain Shams Univ Cairo 10 (2): 493-504 